\title{
Determination of Evapotranspiration and Crop Coefficient of Cactus Pear (Opuntia ficus-indica Mill.) with an Energy Balance Technique
}

\author{
S. Consoli \\ Department of Agro-food and \\ Environmental System Management \\ University of Catania \\ Italy
}

\author{
P. Inglese and G. Inglese \\ Dept. DEMETRA \\ University of Palermo \\ Italy
}

Keywords: irrigation management, micrometeorology, semi-arid climate, surface renewal, water use efficiency

\begin{abstract}
A micrometeorological approach based on surface renewal technique was adopted to estimate evapotranspiration fluxes and crop coefficient data from an irrigated cactus pear (Opuntia ficus-indica Mill.) orchard under Mediterranean climatic conditions. High-frequency temperature readings were taken above the canopy top in order to get surface renewal sensible heat flux values $\left(H_{S R}\right)$. These values were compared against eddy covariance sensible heat fluxes $\left(\mathrm{H}_{\mathrm{EC}}\right)$ for calibration. Latent heat flux (or evapotranspiration, ET) was obtained as the residual of the energy balance equation using $H_{S R}$. In field measurements of biophysical crop features, physiological characteristic and soil hydraulic components were integrated with the analysis of the surface energy fluxes. Microlysimeters were used to compute evaporation rates, allowing the separation of transpiration from ET data. During the irrigation season, evapotranspiration from the cactus pear orchard was $330 \mathrm{~mm}$ of water producing $16,210 \mathrm{~kg}$ of dry matter ha $\mathrm{h}^{-1}$ for a biomass water productivity: $\mathrm{WP}_{\mathrm{b}}=\mathrm{kg}$ biomass $\mathrm{m}^{-2}$ per $\mathrm{kg} \mathrm{H}_{2} \mathrm{O} \mathrm{m}^{-2}=6.6 \times 10^{-3}$. The water use efficiency (WUE) was $204 \mathrm{~kg} \mathrm{H}_{2} \mathrm{O} \mathrm{kg}$ dry matter. The low value of $\mathrm{WP}_{\mathrm{b}}$, relative to other CAM plants, suggests an opportunity to improve the use of irrigation water.
\end{abstract}

\section{INTRODUCTION}

Cactus pear (Opuntia ficus-indica Mill.) is a succulent cacti commercially grown for fruit production. In most countries, but in the native areas of Mexico, the fruit development period coincides with long and dry summers. Despite the water use efficiency of the species reaching values of about $250-300 \mathrm{~kg} \mathrm{H}_{2} \mathrm{O} \mathrm{kg} \mathrm{kg}^{-1}$ dry matter, as reported by De Kock (1980) and Le Houèrou (2000), irrigation is crucial to obtain exportsize fruit quality and increasing marketable yield composition (Snyman, 2006; Gugliuzza and Inglese, 1996). Under these conditions, the eco-physiology advantage of CAM (Crassulacean Acid Metabolism) species can be related to metabolic plasticity in the CAM response to stressful factors (San-José et al., 2007). These traits make cactus pear highly promising as a crop for soils with limited water supply. In fact, it can survive in regions with 200 or $300 \mathrm{~mm}$ of annual rainfall, which are common in arid countries. The idea that cactus pear gives high yield with low input (water and nutrients) is a misconception that was based on little or no scientific information pertaining to the impact of irrigation scheduling on fruit growth and quality (Inglese et al., 2005).

There are few studies on atmospheric conditions and its influence on evapotranspiration (ET) of cacti and other CAM species. Evapotranspiration of cacti was evaluated using the soil water balance technique (Han and Felker, 1997), and measurements of mass $\left(\mathrm{CO}_{2}, \mathrm{H}_{2} \mathrm{O}\right)$ and energy exchanges (solar radiation) for a CAM community was reported by Nobel and Bobich (2002) at the Biosphere 2 Center in Arizona. Micrometeorological approaches might provide a suitable research means to determine ET because CAM species (i.e., cactus pear, pineapple) growth can affect surface forcing conditions and partitioning of available energy into sensible $(\mathrm{H})$ and latent (LE or ET) heat flux densities (Baldocchi, 1994). In this respect, micrometeorological approaches are of particular interest because of their ability to predict surface control of 
energy transfer in terms of canopy and environmental factors (Jarvis and McNaughton, 1986).

In this study, energy flux densities were measured over a cactus pear orchard in Sicily during June-October 2009. The objective of this study was to evaluate the suitability of the surface renewal/energy balance micrometeorological technique to estimate evapotranspiration of cactus pear under semi-arid conditions and to evaluate $\mathrm{WP}_{\mathrm{b}}$.

\section{MATERIALS AND METHODS}

\section{Site Description}

The study was conducted on an experimental field near Roccapalumba $\left(37^{\circ} 48^{\prime} \mathrm{N}\right.$; $13^{\circ} 38^{\prime} \mathrm{E}$; elev. $350 \mathrm{~m}$ ), western Sicily, Italy, from June to October 2009. The semi-arid climate is characterized by a mean annual precipitation of $600 \mathrm{~mm}$. A 2.5-ha cactus pear orchard with cultivars 'Gialla' $90 \%$, 'Rossa' $8 \%$, and 'Bianca' $2 \%$ was selected so that the source area/footprint of the flux measurements remained within the area. Ten-year-old trees were trained to a globe shape. The cacti (maximum height of $3 \mathrm{~m}$ ) were spaced $4 \mathrm{~m}$ within the row and $6 \mathrm{~m}$ between rows giving 416 plants $\mathrm{ha}^{-\mathrm{P}}{ }_{\mathrm{i}}$ Rows were oriented northsouth. The annual marketable production was of 15.0 tons ha ${ }^{-1}$.

According to USDA classification (SCS, 1982), the soil at the experimental field has a clay-loam texture with $40 \%$ sand, $38 \%$ clay, and $22 \%$ silt. Volumetric soil water content was of about $40 \%$ at field capacity, with a saturation surface infiltration rate of $10^{-5} \mathrm{~m} \mathrm{~s}^{-1}$.

The irrigation system consisted of four on-line labyrinth sprayers per plant and a discharge rate of $40 \mathrm{~L} / \mathrm{h}$ per sprayer at a pressure of $150 \mathrm{kPa}$.

\section{Micrometerological Measurements}

Surface Renewal (SR) technique (Paw U et al., 1995; Snyder et al., 1996) was used to measure the sensible heat flux density over the cactus pear orchard from June through October 2009.

The theory of SR considers an air parcel travelling at a given height above the crop. At some instant, the parcel suddenly moves downward (i.e., into the canopy) where it remains for a period of time during which it travels horizontally until the parcel is ejected upwards and replaced by another parcel sweeping in from aloft. During the connect time with the crop, the parcel has been heated (or cooler) because of heat exchange between the air and crop elements.

When high-frequency temperature measurements are collected at fixed point, the renewal process of heated (or cooled) air parcels across a horizontal surface at height $\mathrm{z}$ can be visualized in the time as a regular and low frequency ramp-like pattern (asymmetric triangular shape) (Paw U et al., 1995). A ramp (Fig. 1) is characterized by an amplitude $\left(a,{ }^{\circ} \mathrm{C}\right)$ and the period $(\mathrm{d}+\mathrm{s}, \mathrm{sec})$. In Snyder et al. (2000) high frequency temperature data were processed in a datalogger to output half-hour means of the $2^{\text {nd }}, 3^{\text {rd }}$, and $5^{\text {th }}$ order moments of the time lag temperature differences. Then the moments were uploaded to a computer and analyzed to determine the amplitude (a) and the inverse ramp frequency $(d+s)$ using the Van Atta (1977) structure function methodology. For temperature recorded at plant top, the surface renewal equation for sensible heat flux density $\mathrm{H}$ is expressed as:

$$
\mathrm{H}=\alpha \rho C_{p} \frac{a}{l+s} \cdot z
$$

where $\rho$ and $\mathrm{C}_{\mathrm{p}}$ are the density and the specific heat of dry air at constant pressure, $z$ is the measurement height and $\alpha$ is a calibration factor embodying temperature variation in the canopy.

Two fine-wire thermocouples $(76.2 \mu \mathrm{m}$ dia.) were used in the study to measure 
high frequency $(4 \mathrm{~Hz})$ temperature fluctuations. They were mounted $0.5 \mathrm{~m}$ above the canopy height (at $3.5 \mathrm{~m}$ from soil surface) and SR estimates of $\mathrm{H}$ were computed using a structure function and time lags of 0.25 and 0.50 seconds for each thermocouple to determine the mean ramp-like temperature trace characteristics.

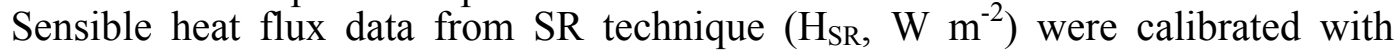
independent eddy covariance (EC) measurements of HEC by one 3-D sonic anemometers located at $3.5 \mathrm{~m}$ from soil surface. The calibration data subset was used to derive the $\alpha$ value of Equation 1 by simple linear regression forced through the origin. For this regression, $\mathrm{H}_{\mathrm{EC}}$ was the dependent and $\mathrm{H}_{\mathrm{SR}}$ was the independent variable. In this way, the regression slope provided the $\alpha$ value to estimate $\mathrm{H}_{\mathrm{EC}}$ from the uncalibrated $\mathrm{SR}$ analysis. The eddy covariance sonic anemometer (Windmaster Pro, Gill Instruments Ltd.) collected the high frequency measurements $(10 \mathrm{~Hz})$ of the three wind components and virtual air temperature. Wind components were rotated to force the mean vertical wind speed fluctuations to zero and to align the horizontal wind speed to the mean streamwise direction (Kaimal and Finningan, 1994).

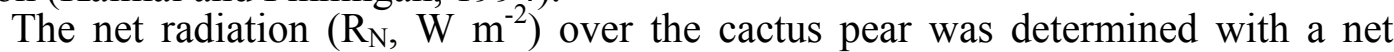
radiometer (NR Lite, Kipp \& Zonen) mounted at $6 \mathrm{~m}$ above the soil surface. Net radiation measurements were representative of the average conditions characterizing the heterogeneous canopy.

At the plot, soil heat flux $\left(\mathrm{G}, \mathrm{W} \mathrm{m}^{-2}\right)$ was measured using a network of three heat flux plates (HFP01, Campbell Scientific Ltd.), which were placed horizontally $0.05 \mathrm{~m}$ below soil surface. The net storage of energy $(\Delta S)$ in the soil column was determined from the soil temperature change taken above each soil heat flux plate during each halfhour sampling period. Three probes (TCAV) were placed in the soil to sample soil temperature. The sensors were placed $0.01-0.04 \mathrm{~m}(\mathrm{z})$ below the surface; the volumetric heat capacity of the soil $\mathrm{C}_{\mathrm{v}}$ was estimated from the volumetric fractions of minerals $\left(\mathrm{V}_{\mathrm{m}}\right)$, organic matter $\left(\mathrm{V}_{0}\right)$ and volumetric water content $(\theta)$. Therefore, $\mathrm{G}$ at the surface was estimated by measuring $G^{\prime}$ at the depth of $0.05 \mathrm{~m}$ and the change in temperature with time of the soil layer above the heat flux plates to determine $\Delta \mathrm{S}$.

$$
\mathrm{G}=\mathrm{G}^{\prime}+\Delta \mathrm{S}=\mathrm{G}^{\prime}+\mathrm{C}_{\mathrm{v}}\left\{\frac{\mathrm{T}_{\mathrm{f}}-\mathrm{T}_{\mathrm{i}}}{\mathrm{t}_{\mathrm{f}}-\mathrm{t}_{\mathrm{i}}}\right\} \cdot \mathrm{d}_{\mathrm{g}}
$$

where $G^{\prime}$ is the heat flux density measured by the plate, $\Delta S$ is the heat storage, $T_{f}$ is the final temperature at time $t_{f}, T_{i}$ is the initial temperature at time $t_{i}$ (the measurement time interval was of $30 \mathrm{~min}), \mathrm{d}_{\mathrm{g}}$ is the depth $(\mathrm{m})$ of the heat flux plates, and $\mathrm{C}_{\mathrm{v}}$ is the volumetric heat capacity $\left(\mathrm{J} \mathrm{m}^{-3} \mathrm{~K}^{-1}\right)$, which depends on the bulk density $\left(\rho_{b}\right)$ of the soil and the volumetric water content $(\theta)$ (De Vries, 1963). Volumetric water content was measured hourly along a vertical profile $0.5 \mathrm{~m}$ deep by using the time domain reflectometry (TDR).

The site was equipped with an automated weather station to measure solar radiation, precipitation, wind speed and direction, air temperature, and relative humidity.

Latent heat flux density was measured as the residual of the energy balance equation:

$$
L E=R_{n}-G-H
$$

where all the terms are in $\mathrm{W} \mathrm{m}^{-2}, R_{n}$ is the net radiation resulting from the balance of all radiation components above the crop, $G$ is the ground heat flux density, and $H$ is the sensible heat flux density, which was determined using the SR technique. Actual crop ET $\left(E T_{c}\right)$ was computed by dividing $L E$ by the latent heat of vaporization: $L=2.45 \mathrm{MJ} \mathrm{kg}^{-1}$.

The crop coefficient $\mathrm{K}_{\mathrm{c}}$ is used to estimate $\mathrm{ET}_{\mathrm{c}}$ from $\mathrm{ET}_{0}$ as:

$$
E T_{c}=K c \cdot E T_{0}
$$


where $E T_{0}$ is the standardized reference evapotranspiration calculated using a modified Penman-Monteith equation (Allen et al., 1998, 2005).

To obtain seasonal estimates, daily soil evaporation was observed over 15-day period in spring-summer (June-July), summer (August-September) and fall (October) with microlysimeter measurements. Small undisturbed soil samples were located in rings of limited height which were closed at the bottom, weighted and reinstalled in the field. The $12.5 \mathrm{~cm}$ long, $11.5-\mathrm{cm}$ diameter microlysimeters were made from $3 \mathrm{~mm}$ thick aluminum pipe. A portable electronic balance was used to weigh the microlysimeters.

The soil characteristics were determined by laboratory test. Ten undisturbed soil samples were collected (using stainless steel cylinders of $10^{-4} \mathrm{~m}^{3}$ inner volume) along a transversal transect at about 0.15 and $0.30 \mathrm{~m}$ deep. In the laboratory, the hydraulic conductivity at saturation, $\mathrm{k}_{\mathrm{S}}$, was determined with the falling-head method by a permeameter. Moisture contents at standard water potential values were determined by a sandbox and a pressure membrane apparatus.

\section{RESULTS AND DISCUSSION}

On a daily basis, the soil heat flux density was generally close to zero. Daily mean sensible heat flux density $(H)$ decreased from $9.3 \mathrm{MJ} \mathrm{m}^{-2} \mathrm{~d}^{-1}$ during late June to $-0.99 \mathrm{MJ}$ $\mathrm{m}^{-2} \mathrm{~d}^{-1}$ in October, with a seasonal mean value of $5.2 \mathrm{MJ} \mathrm{m}^{-2} \mathrm{~d}^{-1}$. Latent heat flux density averaged 6.2 $\mathrm{MJ} \mathrm{m}^{-2} \mathrm{~d}^{-1}$ with extremes of 15.2 and $-1.8 \mathrm{MJ} \mathrm{m}^{-2} \mathrm{~d}^{-1}$. Mean daily values of net radiation $\left(R_{n}\right)$ reached a maximum of $19.0 \mathrm{MJ} \mathrm{m}^{-2} \mathrm{~d}^{-1}$ (Fig. 2). The mean (about 0.55) of daytime evaporative fraction $\left(\mathrm{EF}=\mathrm{LE} / \mathrm{R}_{\mathrm{N}}-\mathrm{G}\right)$ during summer, which characterizes the partition of the energy budget at the daily time scale, varied little (variation of 0.06) based on average cloudiness.

During stable atmospheric conditions, when the available energy $\left(R_{N}-G\right)$ was negative (from around sunset to sunrise) all the fluxes were generally small and ramp amplitude from SR was not well-formed or not in accord with the sign of $\mathrm{H}_{\mathrm{EC}}$. The missing flux was replaced by regression analyses with $\mathrm{H}_{\mathrm{EC}}$ of the whole nighttime pattern. The magnitudes of $\mathrm{H}_{\mathrm{EC}}$ and $\mathrm{H}_{\mathrm{SR}}$ were comparable $\left(\mathrm{R}^{2}=0.92\right)$ regardless of the stability conditions (Figs. 3 and 4).

During daytime stable conditions (i.e., usually in late afternoon), $L E$ was often negative due to low net radiation and air temperature approaching the dew point value.

For low net radiation $\left(<250 \mathrm{~W} \mathrm{~m}^{-2}\right)$, the slope of the relationship between sensible heat flux and net radiation was similar to that of soil heat flux and net radiation. However, the slopes increased and the data were more scattered when net radiation was large. The upward sensible heat flux was greater under unstable conditions when there was more convection from the warmer surface.

Hourly values of $E T_{0}$ and $E T_{\mathrm{c}}$ were plotted together with $\mathrm{K}_{\mathrm{c}}$ values for the cactus pear stand during two periods (Fig. 5). Evapotranspiration from the $\mathrm{H}_{\mathrm{EC}}$ and $\mathrm{H}_{\mathrm{SR}}$ fluxes were compared and plotted in the right-hand chart (Fig. 5). The differences in $E T_{\mathrm{c}}$ were also reflected in the $\mathrm{K}_{\mathrm{c}}$ values. Average values of the midday hourly crop coefficient were $0.53,0.65,0.63$ and 0.60 during June, July, August and September-October periods, respectively (Fig. 5). During the May-October period, mean daily values of $E T_{\mathrm{c}}$ and $E T_{0}$ were 2.5 and $4.4 \mathrm{~mm}$, respectively, with corresponding values of the hourly crop coefficient of 0.58 .

The soil water content from the investigated vertical profile decreased less than $10.0 \mathrm{~mm}$ in the dry season. In general, small changes in soil moisture within 0.15 to $1.0 \mathrm{~m}$ of depth are the result of a significant soil evaporation process (Nobel, 1988; Han and Felker, 1997). The total soil evaporation $E$ was $85 \mathrm{~mm}$ for 132 days with a daily average of $0.64 \mathrm{~mm}$. This corresponds to about $26 \%$ of total $E T_{\mathrm{c}}$ (i.e., $330 \mathrm{~mm}$ ) during the monitoring period. A total of $135 \mathrm{~mm}$ of water was applied by micro-irrigation to the field with a frequency from 4-7 days during the May-September period. The recorded precipitation was $120 \mathrm{~mm}$.

The monitored cladodes internal temperature follows the mean course of the estimated energy fluxes, with maximum temperature values of $43.84^{\circ} \mathrm{C}$. During the 
monitoring period, cacti reached a leaf area index of $2.5 \mathrm{~m}^{2} \mathrm{~m}^{-2}$ with a dry biomass productivity of $16,210 \mathrm{~kg} \mathrm{ha}^{-1}$ year $^{-1}\left(1.621 \mathrm{~kg} \mathrm{~m}^{-2}\right)$ that is comparable to many $\mathrm{C}_{3}$ and $\mathrm{C}_{4}$ plants. The $E T_{\mathrm{c}}$ was $330 \mathrm{~mm}$ and the soil evaporation was estimated as $85 \mathrm{~mm}$. That leads to an estimated seasonal transpiration of $245 \mathrm{~mm}$ or $245 \mathrm{~kg} \mathrm{~m}^{-2}$, so the biomass water productivity was: $\mathrm{WP}_{\mathrm{b}}=\mathrm{kg}$ biomass $\mathrm{m}^{-2}$ per $\mathrm{kg} \mathrm{H}_{2} \mathrm{O} \mathrm{m}^{-2}=6.6 \times 10^{-3}$, which is higher than the $\mathrm{WP}_{\mathrm{b}}$ for $\mathrm{C}_{3}$ and $\mathrm{C}_{4}$ plants but lower than the $\mathrm{WP}_{\mathrm{b}}$ for CAM plants reported by Jones (1992). Calculated water use efficiency (WUE), according to Han and Felker (1997), was $204 \mathrm{~kg} \mathrm{H}_{2} \mathrm{O} \mathrm{kg}^{-1}$ dry matter, greater than that obtained for any plant in other replicated fields trials, and similar to values reported by Le Houérou (2000) (Inglese et al., 2009).

\section{CONCLUSIONS}

Results show that, in a site influenced by semi-arid climate conditions, the SR method is useful and effective for studies requiring the actual evapotranspiration even over CAM vegetation. The technique was able to detect the role of the species to control the available energy partition between different flux densities $(H, G)$. In general, the relatively low-cost SR method provides and excellent approach to obtain evapotranspiration information for irrigation scheduling. In western Sicily, the cactus pear crop was efficient because it tolerates limited rainfall conditions and makes efficient use of water with high productivity. The results indicate that providing crop water requirements for cactus pear could increase yield and quality through better irrigation scheduling. Future studies may relate the physiological status of the plant with micrometeorological information (e.g., gas exchange rate or fruit growth rate pattern versus energy balance).

\section{Literature Cited}

Allen, R.G., Pereira, L.S., Raes, D. and Smith, M. 1998. Crop evapotranspiration: Guidelines for computing crop water requirements. Irr. \& Drain. Paper 56, FAO Rome.

Allen, R.G., Walter, I.A., Elliott, R.L., Howell, T.A., Itenfisu, D., Jensen, M.E. and Snyder, R.L. 2005. The ASCE Standardized Reference Evapotranspiration Equation. Amer. Soc. of Civil Eng. Reston, Virginia. 192p.

Baldocchi, D.D. 1994. A comparison study of mass and energy exchange over a close (wheat) and an open (corn) canopy: I. The partitioning of available energy into latent and sensible heat exchange. Agric. Forest Meteorol. 67:191-200.

De Kock, G.C. 1980. Drought-resistant fodder shrub crops in South Africa. p.339-410. In: H.N. Le Houèrou (ed.), Browse in Africa: the current state of knowledge. International Livestock Centre for Africa, Addis-Ababa.

De Vries, D.A. 1963. Thermal properties of soils, Physics of Plant Environment. Amsterdam, W.R. van Wijk eds. The Netherlands: North-Holland Publishing Co. p.210-235.

Gugliuzza, G., Inglese, P. and Farina, V. 2002. Relationship between fruit thinning and irrigation on determining fruit quality of cactus pear fruits. Acta Hort. 581:221-225.

Han, H. and Felker, P. 1997. Field validation of water-use efficiency of the CAM plant Opuntia ellisiana in south Texas. Journal of Arid Environments 36:133-148.

Inglese, P., Barbera, G. and La Mantia, T. 1995. Research strategies and improvement of cactus pear fruit quality and production. Journal of Arid Environments 29:455-468.

Inglese, P., Barbera, G., Gugliuzza, G. and Liguori G. 2009. Ecophysiology and fruit production of cultivated cacti. p.153-166. In: E. De la Barrera and W.K. Smith (eds.), Perspectives in Biophysical Plant Ecophysiology: A Tribute to Park S. Nobel. Universidad Nacional Autònoma De México.

Jarvis, P.G. and McNaughton, K.G. 1986. Stomatal control of transpiration: Scaling up from leaf to region. Adv. Ecol. Res. 15:1-49.

Jones, H.G. 1992. Plants and Microclimate - A quantitative approach to environmental plant physiology. $2^{\text {nd }}$ Ed. Cambridge Univ. Press. p. 428.

Le Houèrou, H.N. 2000. Cacti (Opuntia spp.) as a fodder crop for marginal lands in the 
mediterranean basin. Acta Hort. 581:21-46.

Nobel, P.S. 1988. Environmental Biology of Agaves and Cacti. Cambridge University Press, Cambridge New York, USA, p. 270.

Nobel, P.S. and Bobich, E. 2002. Initial net $\mathrm{CO}_{2}$ uptake responses and root growth for a CAM community placed in a closed environment. Ann. Bot. 90:93-598.

Paw U, K.T., Qui, J., Su, H.B., Watanabe, T. and Brunet, Y. 1995. Surface renewal analysis: a new method to obtain scalar fluxes without velocity data. Agric. For. Meteorol. 74:119-137.

San José, J.J., Montes, R. and Nikonova, N. 2007. Diurnal patterns of carbon dioxide, water vapour and energy fluxes in pineapple [Ananas comosus (L.) Merr. Cv. Red Spanish] field using eddy covariance. Photosynthetica 45(3):370-384.

Soil Conservation Service (SCS). 1982. Procedures for collecting soil samples and methods of analysis for soil survey. Soil survey investigation report 1, Washington, DC.

Snyder, R.L., Spano, D. and Paw U, K.T. 1996. Surface Renewal analysis for sensible and latent heat flux density. Boundary-Layer Meteorol. 77:249-266.

Snyman, H.A. 2006. Root distribution with changes in distance and depth of two-yearsold cactus pears Opuntia ficus-indica and O. robusta plants. South African J. of Botany 72:434-441.

Van Atta, C.W. 1977. Effect of coherent structures on structure functions of temperature in the atmospheric boundary layer Arch. of Mech. 29:161-171.

\section{Figures}

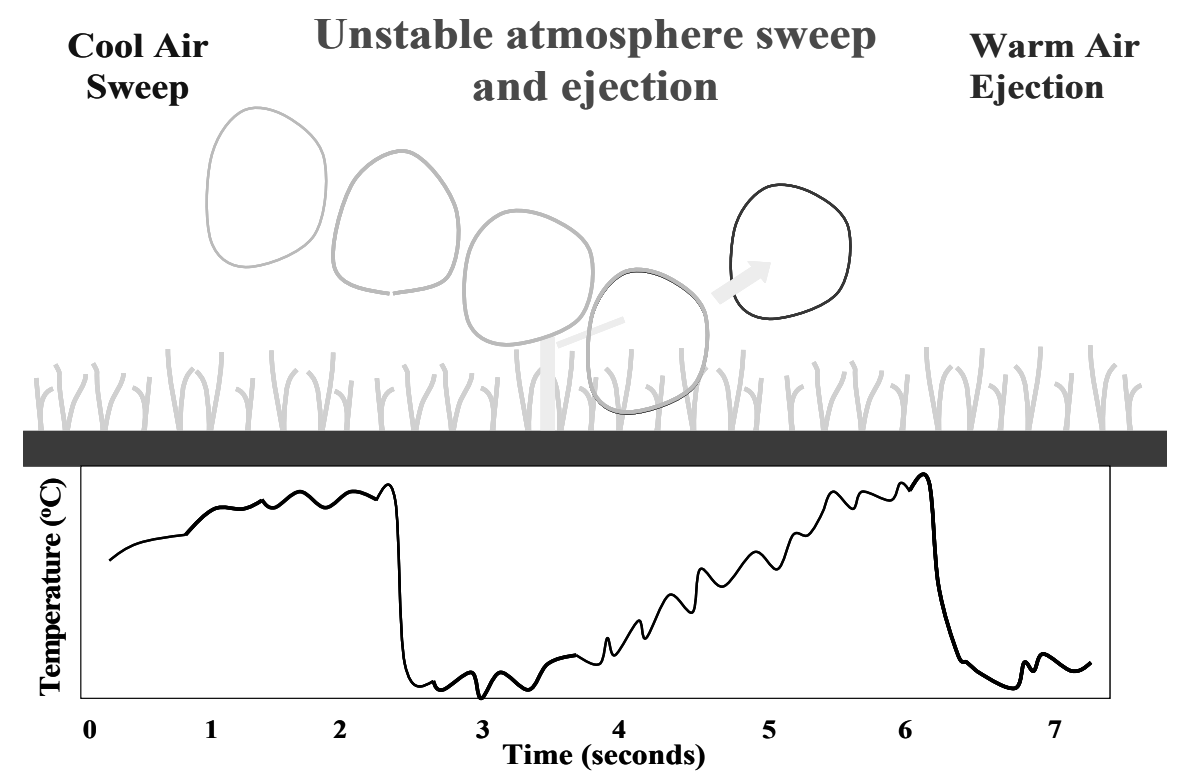

Fig. 1. Air parcel in the renewal process. 


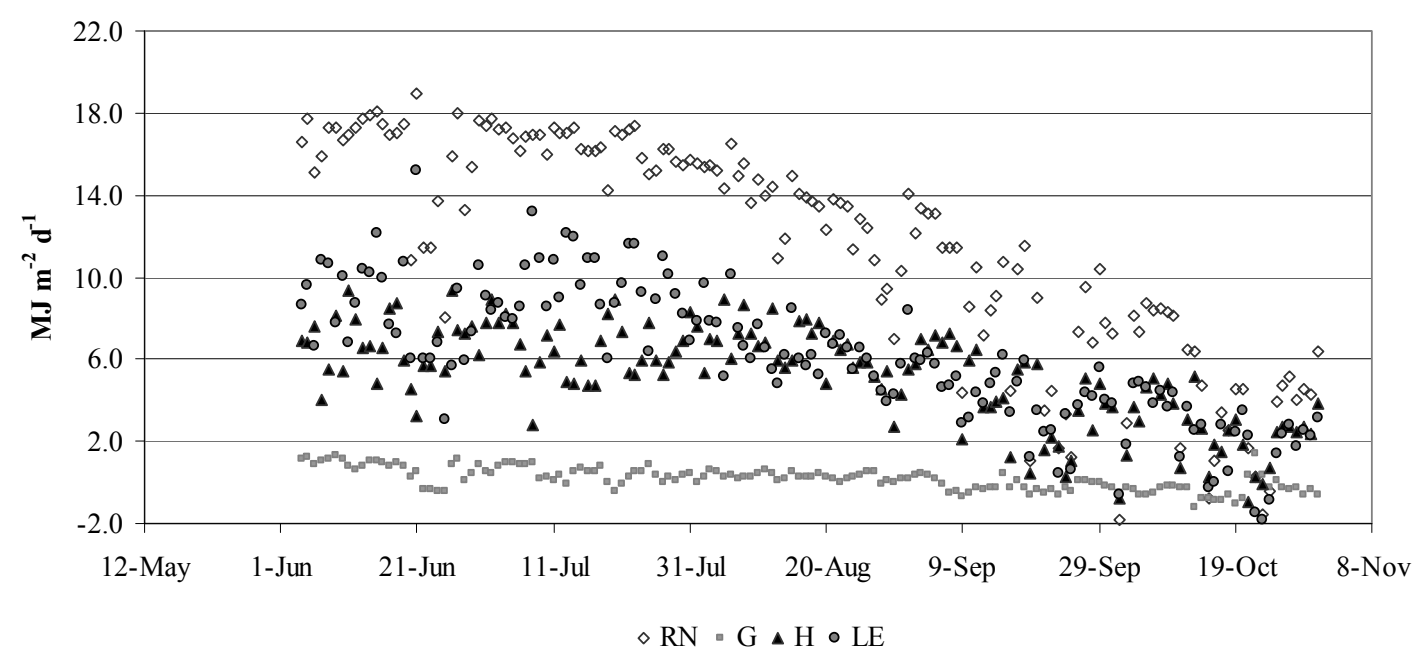

Fig. 2. Daily turbulent fluxes in the cactus pear orchard during June-October 2009.

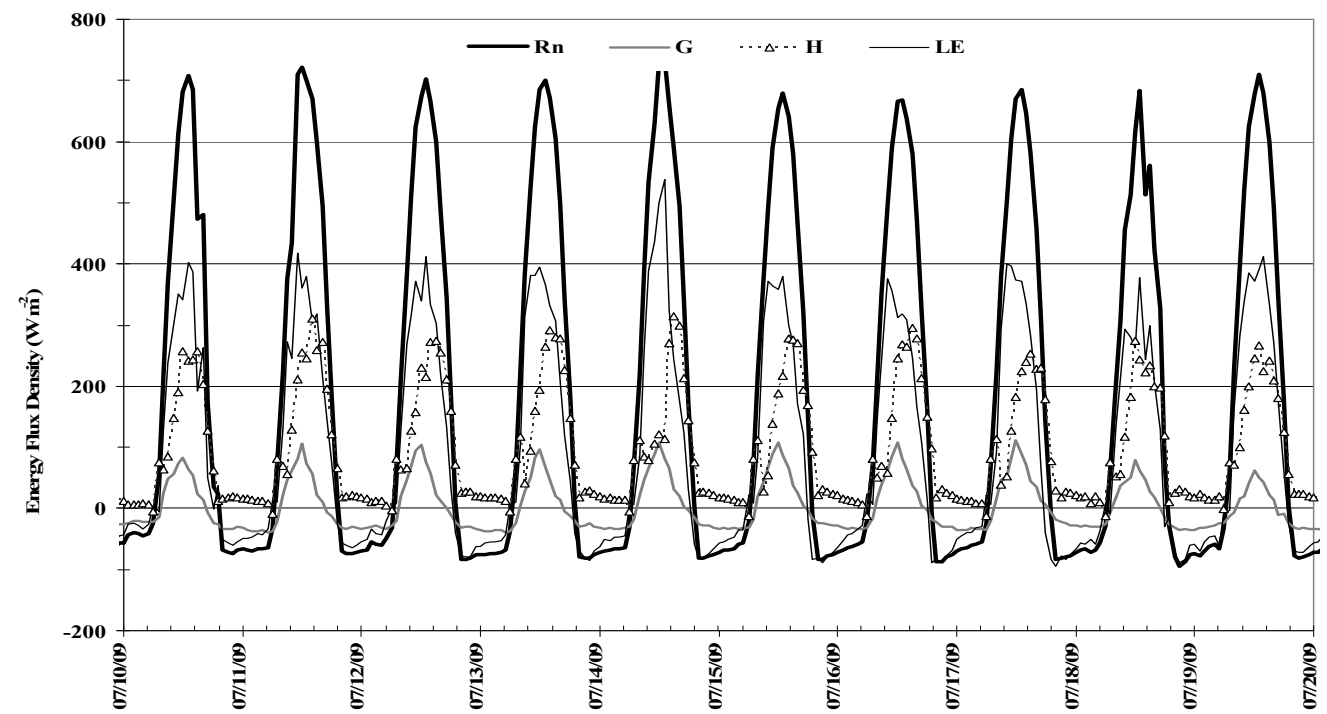

Fig. 3. Example of daily course variation of hourly energy fluxes estimated or directly measured at the experimental site. 


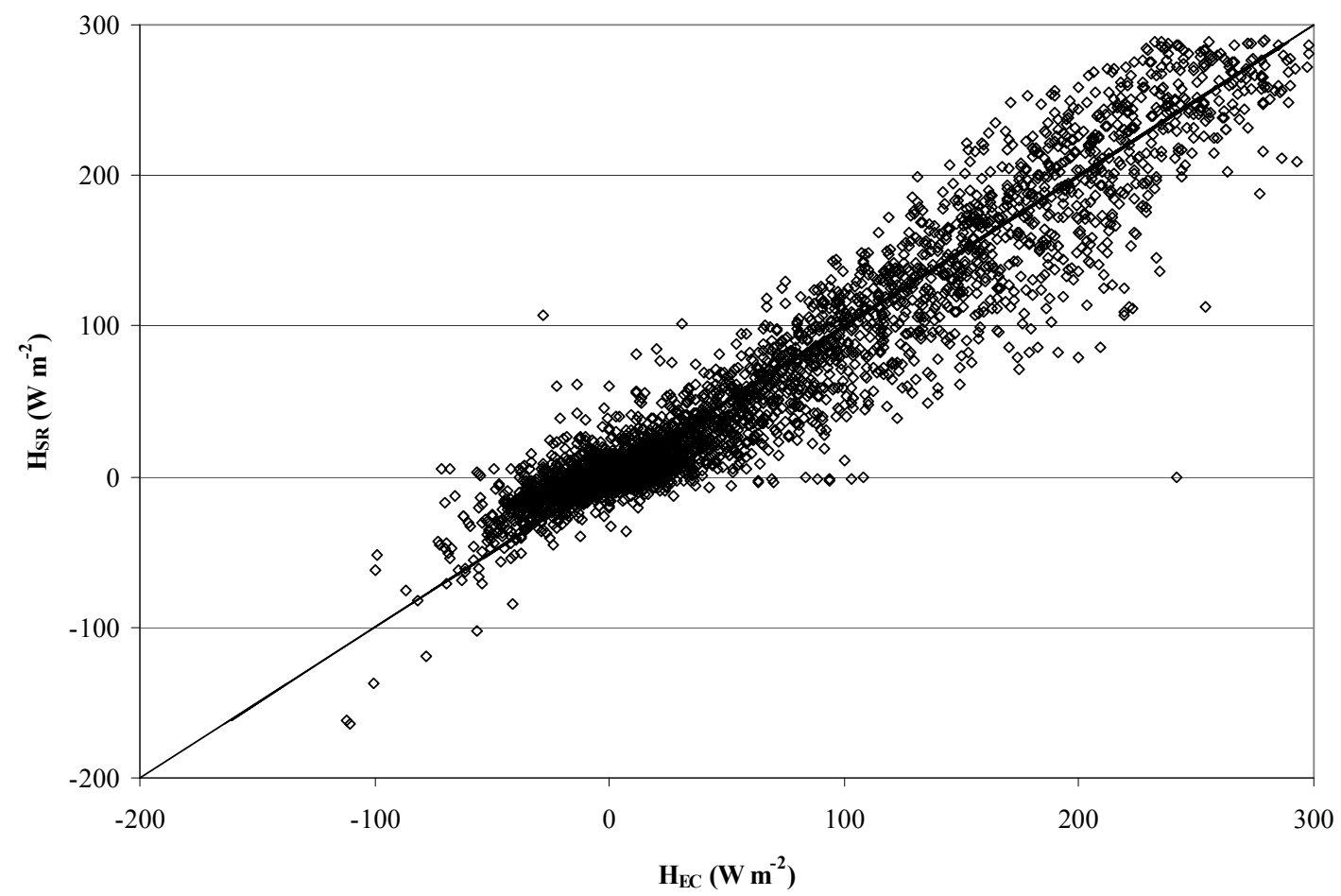

Fig. 4. Sensible heat flux estimates using $\mathrm{SR}$ analysis, $\mathrm{H}_{\mathrm{SR}}$, versus the measured using the EC method, $\mathrm{H}_{\mathrm{EC}}$.

— $\mathrm{ETc} \cdots \cdots \cdot \mathrm{ET} 0 \rightarrow \mathrm{Kc}$

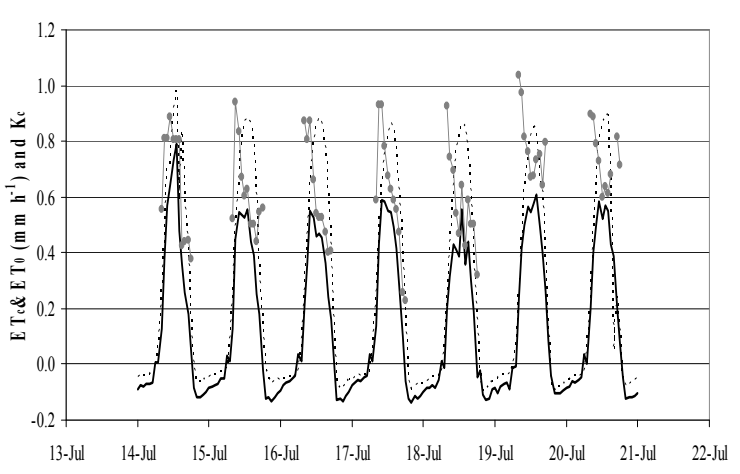

$-\mathrm{ETc} \cdots \cdots \cdot \mathrm{ET} 0 \multimap \mathrm{Kc}-\mathrm{ETc}(\mathrm{EC})$

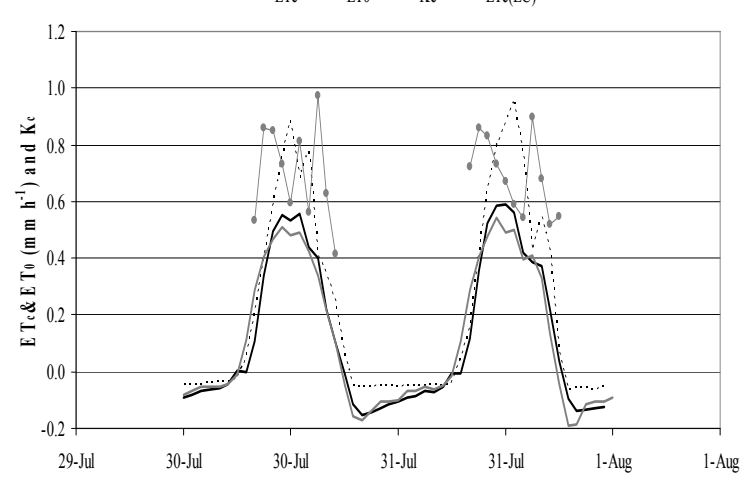

Fig. 5. Hourly reference $\left(E T_{0}\right)$ and crop $\left(E T_{c}\right)$ evapotranspiration plotted together with $\mathrm{K}_{\mathrm{c}}$ values from the $\mathrm{H}_{\mathrm{SR}}$ method during two periods of July 2009. 